Published January 2020

ENGLISH TEACHING AND LINGUISTICS

JOURNAL (ETLiJ)

ISSN 2716-0831 (online) | http://jurnal.umsu.ac.id/index.php/ETLiJ/index

\title{
Critical Discourse Analysis On The Politicians' Social Media Posts
}

\author{
Mandra Saragih ${ }^{1}$ \\ Program Studi Pendidikan Bahasa Inggris \\ University of Muhammadiyah Sumatera Utara \\ Medan, Indonesia \\ mandrasaragih@umsu.ac.id
}

Arika $^{2}$

Program Studi Pendidikan Bahasa Inggris

University of Muhammadiyah Sumatera Utara

Medan, Indonesia

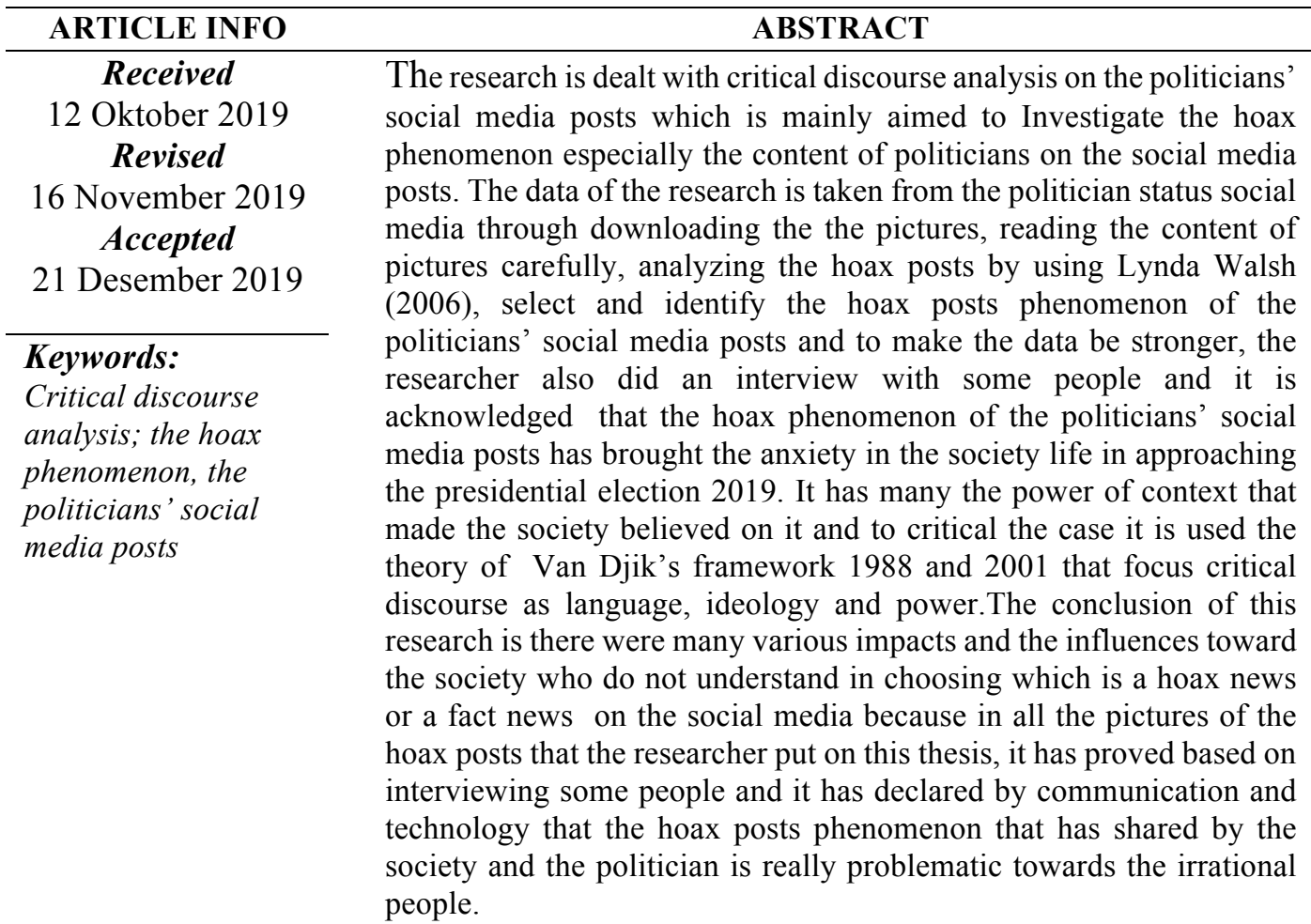

Cara Sitasi:

Saragih, M \& Arika. (2019). Critical Discourse Analysis on the Politicians' Social Media Posts. English Teaching and Linguistics Journal,Vol.1, No. 1, pp.1-4 


\section{INTRODUCTION}

The use of social media such as facebook, instagram, and twitter are known as a tool of facilities and online communications channels which has the design of various forms such as document, video, photo that is actually including a lot of function on sharing the information for every people who use the social media itself in the positive way.

Nowadays, no one can keep the function of social media in the positive way in their life, because they have been being addicted on sharing false information such as hoax issues which exist and as a life trending of everyone. Sharing false information such hoax does not only happen on uneducated person but also on an educated person such as politicians. Politician is actually an educated person who can site in the parliament and they are also as a role model for the society that can imitate their style of an educated person, but unfortunately in the modern life right now we can not see the different between an educated person and uneducated person anymore on the social media posts, it's because of false information which is posted on the social media done by the politician rather than the society.

In approaching the presidential election 2019, sharing about false information such as hoax posts on the social media is being part of trending activity by the politician. The hoax post exists on talking about Jokowi and prabowo as the presidential candidates. As the role model for the society, politicians do that action to influence the society trust on their posts and aims to win their favourite presidential candidate in the election 2019.

Based on the data of Communication and Information Technology (Kemenkominfo) there were 175 hoax pictures that has declared by Kominfo on and the were 30 content of hoax which was related to the election and there was 10 content of hoax post that can influence the society in approaching the presidential election 2019 that has shared the politician such Permadi Arya, Ahmad Dhani, Alfian Tanjung, Ranya Alfarizi and etc.

Based on the data above the hoax post which was shared by politician such PermadiArya, Ahmad Dhani, and AlfianTanjung, AlfianTanjung, RanyaAlfarizi, Daulat, Dalimunte, Ronny Dautak, Rikal Dikri and etccertainly had a lot of negative response influencing the perception of the society which was very appear on the social media and the response and comment which was very exist and appear on te hoax posts itself was the term of Kecebong and Kampret. The term of Kecebong was related to blame Jokowi and Kampret was related to blame Prabowo for spreading hate speech and negative response that can create the society will not respect to their government or to the both candidates which is mandated by many people as the presidential candidate.

By knowing the hoax posts that had a lot of negative responses or comments of spreading hate speech one each other toward both presidential candidate like the case above. The researcher believe that the society easy was to believe about the hoax posts that was shared by the politician and they have difficulty on choosing which one was a good news and a bad news on the social media, therefore they are easy on using the term of Kecebong and Kampret on their comment and based on their comment it's not only be part of negative response but also it's as a small problem which is potentially dangerous that can create a big problem or a big impact such toward Indonesian while approaching the presidential election 2019 
and there will be an anxiety, anti diversity such no one respect each other just because we have different opinion on choosing both presidential candidate.

Based on the case above we know exactly that nobody can avoid the use of social media in our life because we have right to use it, but it doesn't mean we are as Indonesian or as the politician will broke our diversity by sharing the hoax post which has the content that can create anxiety and anti diversity towards our nation while doing the democracy system in approaching the presidential election 2019. As the politician we should realize that sharing the hoax is not a good thing and they should stop to do that to keep up our diversity as well because they are as a role model of society that can influence the society will be trusted on them in various of their hoax post which is shared before. Beside that talking about spreadingthe hoax posts itself also has the role of information law and electronic technology 28 to not sharing the hoax information on the social media and if there are many the societies or the politicians' do that thing, They will be punished for 6 years.

In conclusion, the researcher was interested in conducting a Critical Discourse Analysis because Critical Discourse analysis is a study that aims to provide a thorough description, explanation, and critique of the textual strategies that the writers use to naturalize discourse. By using Critical Discourse Analysis on the hoax post which is including the content that blame both candidates of the presidential election 2019 the researcher attempts it in order to have a better understanding toward responses of hoax post, it's impact to the society and how is the hoax can influence the societies.

\section{METHODS}

This research was conducted by using descriptive qualitative method by mainly by applying the data and analysing the data to describe the data. This method used in order to discover, identify, analyse and describe critical discourse analysis of on the hoax phenomenon of the politicians' social media posts in approaching the presidential election 2019 specially to understand the hoax post and the realization of hoax that the hoax phenomonen of the politicians' social media posts has the impact and a big problem toward the diversity in Indonesia for approaching the presidential election 2019. Qualitative methhod is a method which is used to make a description of situation, event or occurence in accumulating the data (Muri Yusuf, 2014).

\section{RESULT AND DISCUSSION}

After analyzing the data from the ministry of communication and information, the finding can be presented as follows:

1. The hoax post was so many spread on the social media and it has spread or shared by the politician who has the power,

2. There were 10 hoax post which was related to the approaching the presidential election 2019 that has shared by the politician,

3. The hoax post can be influenced toward the irrational people because they did not understand how to choose the news which is true or not.

Based on the data, there were there were 175 of hoax post and there were 30 the hoax post which is related to the presidential election but only 10 the hoax posts 
that has shared by the politician that related to the approaching the presidential 2019. It is analyze that all the post has declared as the hoax post by the ministry of communication and information and based on the data of it the hoax post has the content that related to the hate speech and can create the term of Kecebong and Kampret and at the end it can also create the anxiety, anti diversity among the society, beside that the hoax post itself can be influenced by many people because it has shared by the people who has the power that can change the mindset of the irrational people believe on that case.

\section{SUGGESTION AND CONCLUSION}

After analyzing the data of hoax phenomenon on the social media posts's which is taken from the data of communication and technology, the researcher hopes that:

1. Reader: they can improve their knowledge on choosing which is a hoax news or a fact news on their social media by using the ministry of communication and information.

2. Other researchers: they can get more knowledge of the hoax post by using the ministry of communication and information

From the explanation above, it can be concluded that:

1. There were many various impacts and the influences toward the society who do not understand in choosing which was a hoax news or a fact news on the social media and the various impacts were such as Hate speech, anxiety, and Anti Diversity

2. The hoax post can influence towards the society because some of the hoax post was coming up from the politician who has the power that can create the society such as the irrational people would trust of the hoax post itself

\section{REFERENCES}

Fairclough, N., \&Wodak, R. 1997. Critical discourse analysis. In T. van Dijk (Ed.), Discourse as social interaction (pp. 258-284). London: SagePublications

Lynda Walsh, 2006, Theory of Hoax. England.

Muri Yusuf, 2014. Qualitative Method Research. Jakarta

Rogers, R., Berkes, L, M., Mosley, M., Hui, D., \& Joseph, G. O. 2005. Critical discourse analysis in education: A review of the literature. Review of Education Research, 75(3), 365-416.

SahrulMaulidi, 2018. CerdasMenghadapiPencemaranNamaBaikdan Hoax. Jakarta.

Taiwo, R. 2007. Language, ideology and power relations in Nigerian newspaper headlines. Nebula, 4 (1), 218-245.

Van Dijk, T. A. 1993. Principles of critical discourse analysis. Discourse and Society, 4(2), 249-283.

Van Dijk, T. A. 1988b. News analysis. Hillsdale: Erlbaum.

Van Dijk, T. A. 2001. Critical discourse analysis.Handbook of discourse analysis.Oxford Blackwell.

Wodak, R., \& Meyer, M. 2008. Critical discourse analysis: History, agenda, theory, and methodology. Sage publications.

http:// Kominfo.go.id 21;30 (Friday, 1/3/2019) 